\title{
Zika virus disease
}

INSERM

\section{Source}

INSERM. (1999). Orphanet: an online rare disease and orphan drug data base. Zika virus disease. ORPHA:448237

Zika virus disease is an emerging Aedes mosquito-born virus disease characterized by a clinical course that may be asymptomatic or mild with fever, conjunctivitis, muscle and joint pain, headache, exanthema, but may also be associated with severe neurological (mening itis, meningoencephalitis and myelitis) and auto-immune (Guillain-Barre syndrome) complications, as well as a potential increase of birth defects (microcephaly) if the infection occurs during pregnancy. 